\title{
Data Migration Technique Options on Reforming Jiwasraya's Existing Database
}

\author{
Vellyne Tjiam $^{*}$, William Chrisandy ${ }^{2}$, William Chrisandy ${ }^{3}$, \\ Karel Alexander ${ }^{4}$ \\ ${ }_{1,4}$ Computer Science Department, School of Computer Science, \\ ${ }^{2,3}$ Mobile Application and Technology Program, Computer Science Department, School of Computer Science, \\ Bina Nusantara University \\ Jakarta, Indonesia 11480 \\ vellyne.tjiam@binus.ac.id; william.chrisandy@binus.ac.id; hanna.savira@binus.ac.id; \\ karel.alexander@binus.ac.id
}

*Correspondence: vellyne.tjiam@binus.ac.id

\begin{abstract}
PT Asuransi Jiwasraya has been facing a crisis since 2020, which later probably demand them to reconstruct their insurance policy. Nothing is decided aside from the reconstruction idea. This is a hard task to deal with as there is a high risk to be borne along. In the worst case, bankruptcy awaits. As technology has taken over most industries, including insurance, it is only normal for the company to take advantage of the applied technology. However, it is still unknown whether the database used could help fulfill the mission. Considering loads of data might be higher by year, it will be more efficient to use the integrated database to transfer the whole data into a new-adapted database rather than creating a new one and manually adapt then add the data. This could be done by doing a Bottom-up approach that occurs in two big steps. This is the safest choice now which is handy and possible.
\end{abstract}

Keywords: Database Integration; Digital Technology in Insurance, Jiwasraya Insurance.

\section{INTRODUCTION}

Insurance has been one familiar aspect of society. As life provides nothing but uncertainty, people go for insurance to get assurance in return. Therefore, the insurance industry is considered as one of the high growth fields nowadays. Exceedingly, the COVID-19 breakout brings horror along. No wonder the number of insurance companies increases as the customer rate soared.

PT Asuransi Jiwasraya was one of them. However, a case of corruption goes public in 2020, resulting in a decrease in fame. The case has been in progress. According to Trihatmoko and Kuncoro (2021), this would be solved by either liquidation, recapitalization, merger and holding, privatization, or recapitalization and privatization.
Whichever way, there is one sure impact left by this problem, there would be a need to do reconstruction on their insurance policy that results on their whole database. In this study, we ought to analyze how the database usage is going to leave an outcome.

The database has been widely used as a method of data management. Almost every industry has been in touch with the database concept itself as each has loads of data stored for needs. However, not so many cases require mass data movement, nor reconstruction. As for PT Asuransi Jiwasraya, it is one of the biggest steps to work on after the announcement of their insurance policy reconstruction to lessen the loss caused by corruption.

This means the whole database is going to be readapted as insurance policy plays the primary key role and is most likely always related to any other data stored. It is still unknown if the usage of the database itself brought convenience to the process or otherwise. Therefore, we try to study how the database using both, directly and indirectly, affects this whole project. While working on it, we would like to find out which method best suited the requirements of this case.

PT Asuransi Jiwasraya is an insurance company with one hundred and sixty years of journey. Throughout the journey, it had gained its investors' trust with great financial statements from year to year. However, in 2019, the company suffered a big amount of loss that comes around sixty-two trillion rupiahs (Gusti, 2019). Around forty-nine trillion was counted as debt. This is a long-time loss calculated by years as Jiwasraya has always faked its financial statements, but it came big because the management of Jiwasraya, unfortunately, placed a wrong investment that was soon tailed with a bigger loss. 


\section{METHODS}

This research was conducted using the literature review method of study. Therefore, we analyzed the case based on the previous example collected in the field of the database, insurance, and digitalization. To tone down the topic, we used one research question as our focus.

\subsection{Literature Study}

As for data and information collecting regarding the topic, we used https://scholar.google.com as our main search engine with database, distributed database, database integration, technology, insurance, Jiwasraya Insurance, database in an insurance company, digital technology in insurance, and digitalization in insurance as our keywords. From approximately fifty-three papers regarding the mentioned issue, we filtered them down based on their publication year and only used those published among the last five years as reference. A similar case was not found, but we believe other cases could also bring justice to this study. Thus, we ended using nineteen papers which we concluded as the most relatable ones.

\subsection{Research Question}

The main purpose of this research is to answer how does database relates to the policy reconstruction of PT Asuransi Jiwasraya. Recently, Jiwasraya suffered a huge loss due to several committed corruption inside the company. This surely gained a lot of interest. So, to prevent anger from both public and existing customers, Jiwasraya goes down the option of restructuring policies that can be saved. Far before the case itself, Jiwasraya has always been using a database as their way of storing and managing data that has become one with their system. In this process, the database will be cleaned as Jiwasraya goes back in touch with their customer by accessing the stored data. Customers' data will be checked again if they are willing to deal with a new policy and updated if needed. Otherwise, all the data will vanish. Upon the fresh data, Jiwasraya may start to move the latest and corresponding data to a new database.

\section{RESULTS AND DISCUSSION}

Based on the literature review done, there are several possibilities that we cannot overlook. Most of the research we have studied points out a few possibilities available.

\subsection{Solutions}

PT Asuransi Jiwasraya has been known to experience a serious problem which issue starts at the beginning of 2020 (Trihatmoko et al., 2021). The case was said to face two dilemmatic choices between "the company to be liquidated or run again". However, it

Table 1 List of Relevant Publications

\begin{tabular}{|c|c|c|c|c|c|c|c|c|}
\hline No & Title & Author & $\begin{array}{l}\text { Publication } \\
\text { Year }\end{array}$ & Purpose & Method and Model & $\begin{array}{l}\text { Dataset/ } \\
\text { Sample }\end{array}$ & Evaluation \& Result & Conclusion \\
\hline 1 & $\begin{array}{c}\text { Enhance } \\
\text { Confidentiality } \\
\text { by the usage } \\
\text { of a Database } \\
\text { Management } \\
\text { Framework } \\
\text { Features to } \\
\text { Facilitate } \\
\text { Applications } \\
\text { Integration }\end{array}$ & $\begin{array}{l}\text { Iqbal, H., } \\
\text { Habli, M., \& } \\
\text { Zeki, T. }\end{array}$ & 2020 & $\begin{array}{l}\text { To find a way } \\
\text { to improve the } \\
\text { efficiency of file } \\
\text { sharing using } \\
\text { database management } \\
\text { framework features. }\end{array}$ & $\begin{array}{c}\text { Research Work, } \\
\text { Proposal Design, The } \\
\text { Prototype }\end{array}$ & 8 & $\begin{array}{l}\text { Development of SAQELSq1 query } \\
\text { interface to remove the need in } \\
\text { the name and key of the customer, } \\
\text { provide additional details about the } \\
\text { efficiency of operations, exploring } \\
\text { how to return details about the } \\
\text { implementation directly through } \\
\text { DB2 application, and how to stop } \\
\text { using an automatic failover to do so. }\end{array}$ & $\begin{array}{l}\text { There is a way to improve the } \\
\text { efficiency of file sharing using } \\
\text { database management framework } \\
\text { features, which will include various } \\
\text { software and searching for DB2 } \\
\text { software to install SAS systems. }\end{array}$ \\
\hline 2 & $\begin{array}{l}\text { Insurance } \\
\text { Transformed } \\
\text { Technological } \\
\text { Disruption }\end{array}$ & Naylor, M. & 2017 & $\begin{array}{c}\text { To show how } \\
\text { technology } \\
\text { transforms the } \\
\text { industry of insurance. }\end{array}$ & $\begin{array}{l}\text { Qualitative research } \\
\text { by studying literature } \\
\text { related to the topic. }\end{array}$ & 20 & $\begin{array}{l}\text { Technological disruption brings a } \\
\text { reduction in human services costs. }\end{array}$ & $\begin{array}{l}\text { Technology transforms the } \\
\text { insurance industry from an } \\
\text { economical side by reducing } \\
\text { human services costs. }\end{array}$ \\
\hline 3 & $\begin{array}{l}\text { Use of } \\
\text { Information } \\
\text { Technology } \\
\text { in Insurance } \\
\text { Industry }\end{array}$ & Shinde, O. & 2019 & $\begin{array}{l}\text { To help readers } \\
\text { understand and } \\
\text { highlight the } \\
\text { importance of } \\
\text { Information } \\
\text { Technology in the } \\
\text { Insurance Industry. }\end{array}$ & $\begin{array}{l}\text { Qualitative research } \\
\text { by studying literature } \\
\text { related to the topic. }\end{array}$ & Various & $\begin{array}{l}\text { There are demands of technology } \\
\text { usage as the trend changes and } \\
\text { customers' demand raises, so } \\
\text { insurance companies should be } \\
\text { aware and able to identify the } \\
\text { specific needs to offer relevant } \\
\text { products and services to their } \\
\text { customers. }\end{array}$ & $\begin{array}{l}\text { Information Technology is } \\
\text { concluded as something important } \\
\text { as the existing technologies } \\
\text { have been seriously taken into } \\
\text { consideration while calculating } \\
\text { potential advantages and costs for } \\
\text { installing such technologies. The } \\
\text { bigger the company is, the bigger } \\
\text { needs and costs await }\end{array}$ \\
\hline 4 & $\begin{array}{l}\text { Impact of } \\
\text { Technology } \\
\text { on Insurance } \\
\text { Industry }\end{array}$ & Mosleh, N. & 2019 & $\begin{array}{l}\text { To show how big the } \\
\text { growth of technology } \\
\text { affects and challenges } \\
\text { the insurance } \\
\text { industry. }\end{array}$ & $\begin{array}{l}\text { Qualitative research } \\
\text { by studying gained } \\
\text { information and data } \\
\text { related to the topic } \\
\text { to generate a specific } \\
\text { conclusion. }\end{array}$ & Various & $\begin{array}{l}\text { There would be lots of profits } \\
\text { and challenges along the way } \\
\text { so mentorship, apprenticeship, } \\
\text { and training must be utilized to } \\
\text { rejuvenate the workforce after the } \\
\text { old generation exit, and insurers } \\
\text { should embrace the radical and } \\
\text { incremental technology innovations } \\
\text { to enhance their insurance products } \\
\text { and explore new distribution } \\
\text { channels to be able to survive and } \\
\text { overcome the future challenges. }\end{array}$ & $\begin{array}{l}\text { The industry is extremely affected } \\
\text { by technology as it is poised to } \\
\text { affect beneficial means by which } \\
\text { it will cater to the challenging } \\
\text { times ahead while it continues to } \\
\text { do business. So, the industry itself } \\
\text { needs to adapt depending on the } \\
\text { growth process of technology. }\end{array}$ \\
\hline 5 & $\begin{array}{l}\text { Contribution } \\
\text { of Technology } \\
\text { to Insurance in } \\
\text { Indonesia }\end{array}$ & Safitri, K. A. & 2020 & $\begin{array}{l}\text { To describe } \\
\text { how technology } \\
\text { contributes to } \\
\text { the development } \\
\text { of insurance in } \\
\text { Indonesia. }\end{array}$ & $\begin{array}{l}\text { Qualitative research } \\
\text { by doing a literature } \\
\text { review and followed } \\
\text { by hypothesis testing. }\end{array}$ & 13 & $\begin{array}{l}\text { Insurance industry policymakers } \\
\text { should start developing online } \\
\text { premium policies and online claim } \\
\text { systems. }\end{array}$ & $\begin{array}{l}\text { The technology could contribute to } \\
\text { the development of the insurance } \\
\text { industry in Indonesia by providing } \\
\text { online services like premium } \\
\text { policies and a claim system. }\end{array}$ \\
\hline 6 & $\begin{array}{l}\text { Application } \\
\text { of Big Data } \\
\text { Technology } \\
\text { in Insurance } \\
\text { Innovation }\end{array}$ & $\begin{array}{l}\text { Zheng, L., \& } \\
\text { Guo, L. }\end{array}$ & 2020 & $\begin{array}{l}\text { To learn how big the } \\
\text { influence left by the } \\
\text { application of big } \\
\text { data to the insurance } \\
\text { industry. }\end{array}$ & $\begin{array}{c}\text { Qualitative research } \\
\text { by doing a literature } \\
\text { review and followed } \\
\text { by an analysis of past } \\
\text { cases. }\end{array}$ & Various & $\begin{array}{l}\text { Digital technology represented by } \\
\text { the Internet, mobile networks, social } \\
\text { networks, cloud computing, and } \\
\text { big data increasingly influences the } \\
\text { daily operation of the industry and } \\
\text { will usher in a golden development } \\
\text { period in China's insurance industry. }\end{array}$ & $\begin{array}{l}\text { The application of big data leaves } \\
\text { more positive sides to the insurance } \\
\text { industry, but the fact that there } \\
\text { are challenges brought could not } \\
\text { be ignored. Thus, strategies are } \\
\text { needed. }\end{array}$ \\
\hline
\end{tabular}




\begin{tabular}{|c|c|c|c|c|c|c|c|c|}
\hline 7 & $\begin{array}{l}\text { Is Distributed } \\
\text { Database } \\
\text { Evaluation }\end{array}$ & $\begin{array}{c}\text { Seybold, } \\
\text { D., \& } \\
\text { Domaschka, J. }\end{array}$ & 2017 & $\begin{array}{l}\text { To ensure how } \\
\text { ready the distributed } \\
\text { database evaluation } \\
\text { cloud is to be used. }\end{array}$ & $\begin{array}{l}\text { Qualitative research } \\
\text { by doing literature } \\
\text { reviews and followed } \\
\text { by an analysis of } \\
\text { current framework } \\
\text { compared to the ideal } \\
\text { achievement wanted. }\end{array}$ & 8 & $\begin{array}{l}\text { The result of this analysis shows } \\
\text { that the performance, scalability, } \\
\text { elasticity, and consistency tiers } \\
\text { are well covered, while resource } \\
\text { selection and availability are } \\
\text { not considered by existing } \\
\text { evaluation frameworks. Traditional } \\
\text { requirements are covered, while } \\
\text { cloud-centric requirements such } \\
\text { as orchestration are only partially } \\
\text { supported. }\end{array}$ & $\begin{array}{l}\text { The distributed database evaluation } \\
\text { cloud is only half ready so it's not } \\
\text { yet able to be used }\end{array}$ \\
\hline 8 & $\begin{array}{l}\text { Distributed } \\
\text { Database } \\
\text { Problems, } \\
\text { Approaches and } \\
\text { Solutions-A } \\
\quad \text { Study }\end{array}$ & $\begin{array}{l}\text { Rana, M. S., } \\
\text { Sohel, M. K., } \\
\text { \& Arman, } \\
\text { M. S. }\end{array}$ & 2018 & $\begin{array}{l}\text { To learn the problems } \\
\text { that usually occur on } \\
\text { distributed databases } \\
\text { and find both the } \\
\text { best approaches and } \\
\text { solutions which suit } \\
\text { the case. }\end{array}$ & $\begin{array}{l}\text { Qualitative research } \\
\text { by doing literature } \\
\text { review with case } \\
\text { study approach on } \\
\text { similar cases. }\end{array}$ & Various & $\begin{array}{l}\text { Each approach suits only some kind } \\
\text { of case, it is important to learn the } \\
\text { case thoroughly before choosing an } \\
\text { approach and solution. To maintain } \\
\text { mutually reliable data in all sites, } \\
\text { replication control procedures need } \\
\text { to be implemented. }\end{array}$ & $\begin{array}{l}\text { The problem areas declared in } \\
\text { the paper are very useful while } \\
\text { implementing distributed database } \\
\text { so that concurrency, deadlock, } \\
\text { replication control, security, and } \\
\text { privacy is easily managed. Yet, } \\
\text { each case has its own best approach } \\
\text { and solution for sure. }\end{array}$ \\
\hline 9 & $\begin{array}{c}\text { Database } \\
\text { Integration Based } \\
\text { on Combination } \\
\text { Schema Matching } \\
\text { Approach } \\
\text { (Case Study: } \\
\text { Multi-database } \\
\text { of District Health } \\
\text { Information } \\
\text { System) }\end{array}$ & $\begin{array}{l}\text { Rachman, } \\
\text { M. A. F., \& } \\
\text { Saptawati, G. } \\
\text { A. P. }\end{array}$ & 2017 & $\begin{array}{l}\text { To learn how the } \\
\text { multi-database of } \\
\text { District Health } \\
\text { Information System } \\
\text { is best integrated. }\end{array}$ & $\begin{array}{l}\text { Qualitative research } \\
\text { by doing literature } \\
\text { reviews and followed } \\
\text { by experiments on } \\
\text { datasets. }\end{array}$ & 3 & $\begin{array}{l}\text { From some experiments that have } \\
\text { been done considering the elements } \\
\text { of semantic conflict on schema } \\
\text { identification, hybrid combination } \\
\text { schema matching can be used for } \\
\text { query rewriting on multi-databases. } \\
\text { The limitations of this research } \\
\text { are: (1) element-level matching is } \\
\text { restricted to local cardinalities of } \\
1: 1 \text {, and (2) query rewriting is still } \\
\text { limited to the same DBMS. For } \\
\text { future work, the schema matching } \\
\text { techniques that have been used can } \\
\text { be combined with other techniques } \\
\text { to produce a more accurate matching } \\
\text { schema in query rewriting. }\end{array}$ & $\begin{array}{l}\text { Hybrid combination schema } \\
\text { matching can be used for query } \\
\text { rewriting on multi-databases to } \\
\text { meet the best-integrated condition, } \\
\text { but there are some limitations. So, } \\
\text { it would be better if combined with } \\
\text { other techniques. }\end{array}$ \\
\hline 10 & $\begin{array}{l}\text { A Review on } \\
\text { the Settlement } \\
\text { of 'Jiwasraya' } \\
\text { Case: A Study } \\
\text { of Governance } \\
\text { of State-Owned } \\
\text { Enterprises } \\
\text { (SOEs) Based on } \\
\text { the Indonesian } \\
\text { Economic } \\
\text { Constitution }\end{array}$ & $\begin{array}{l}\text { Trihatmoko, } \\
\text { R. A., \& } \\
\text { Kuncoro, M }\end{array}$ & 2021 & $\begin{array}{l}\text { To study how the } \\
\text { case of PT Asuransi } \\
\text { Jiwasraya is possibly } \\
\text { going to be settled. }\end{array}$ & $\begin{array}{l}\text { Qualitative research } \\
\text { by doing literature } \\
\text { review with case } \\
\text { study approach on } \\
\text { similar cases. }\end{array}$ & 50 & $\begin{array}{l}\text { Constitutionally the government } \\
\text { could take policies in solving } \\
\text { the Jiwasraya case, namely } \\
\text { liquidation, recapitalization, merger } \\
\text { and holding, privatization, or } \\
\text { recapitalization and privatization. }\end{array}$ & $\begin{array}{l}\text { The case of PT Asuransi Jiwasraya } \\
\text { is possibly going to be solved } \\
\text { by liquidation, recapitalization, } \\
\text { merger, and holding, privatization, } \\
\text { or recapitalization and an } \\
\text { privatization. }\end{array}$ \\
\hline 11 & $\begin{array}{l}\text { Big Data Platform } \\
\text { Architecture } \\
\text { under The } \\
\text { Background } \\
\text { of Financial } \\
\text { Technology: In } \\
\text { the Insurance } \\
\text { Industry as An } \\
\text { Example }\end{array}$ & $\begin{array}{l}\text { Yi Liu, Jiawen } \\
\text { Peng, and } \\
\text { Zhihao Yu }\end{array}$ & 2018 & $\begin{array}{l}\text { improving financial } \\
\text { efficiency and } \\
\text { reducing the cost of } \\
\text { financial transactions } \\
\text { is an important driver } \\
\text { in insurance. }\end{array}$ & Qualitative Research & 16 & $\begin{array}{l}\text { As big data technology matures, } \\
\text { sparks collide with each other } \\
\text { innumerable }\end{array}$ & $\begin{array}{l}\text { Big Data platforms combined with } \\
\text { space-time data can integrate their } \\
\text { own data resources but can also } \\
\text { come from many products, on } \\
\text { cost reduction, risk prevention in } \\
\text { business is helpful. }\end{array}$ \\
\hline 12 & $\begin{array}{l}\text { Digital } \\
\text { technology in } \\
\text { insurance }\end{array}$ & $\begin{array}{l}\text { A. A. } \\
\text { Mustafina, } \\
\text { G. N. } \\
\text { Kaigorodova, } \\
\text { P. D. } \\
\text { Alyakina, N. } \\
\text { Y. Velichko, } \\
\text { and M. R. } \\
\text { Zainullina }\end{array}$ & 2020 & $\begin{array}{l}\text { studying the impact } \\
\text { of information } \\
\text { technology on the } \\
\text { development of direct } \\
\text { insurance in Russia. }\end{array}$ & $\begin{array}{l}\text { Mixed-methods } \\
\text { Methodology }\end{array}$ & 20 & $\begin{array}{l}85 \% \text { of insurance companies use } \\
\text { IT solutions in the sales process. } \\
\text { Currently, } 75 \% \text { of insurance } \\
\text { companies are engaged in the } \\
\text { introduction of new IT products and } \\
\text { solutions. }\end{array}$ & $\begin{array}{l}\text { Research materials are practically } \\
\text { important for insurance companies, } \\
\text { as they provide the concept of } \\
\text { correlation between the digitization } \\
\text { of the business and its level of } \\
\text { profitability. }\end{array}$ \\
\hline 13 & $\begin{array}{l}\text { Wearables and the } \\
\text { internet of things: } \\
\text { Considerations } \\
\text { for the life and } \\
\text { health insurance } \\
\text { industry }\end{array}$ & $\begin{array}{l}\text { A. Spender, } \\
\text { C. Bullen, L. } \\
\text { Altmann- } \\
\text { Richer, J. } \\
\text { Cripps, R. } \\
\text { Duffy, C. } \\
\text { Falkous, } \\
\text { M. Farrell, } \\
\text { T. Horn, J. } \\
\text { Wigzell, and } \\
\text { W. Yeap }\end{array}$ & 2019 & $\begin{array}{l}\text { to see the emergence } \\
\text { of wearable } \\
\text { technology and the } \\
\text { internet of things } \\
\text { (IoT) and its current } \\
\text { and potential use in } \\
\text { the areas of health } \\
\text { and care. }\end{array}$ & Qualitative Research & 51 & $\begin{array}{l}\text { general insurance community } \\
\text { faster acting and products that } \\
\text { integrate technology to improve the } \\
\text { quality of underwriting and claims } \\
\text { management become more common }\end{array}$ & $\begin{array}{l}\text { Technology may be a major } \\
\text { opportunity and threat to the } \\
\text { insurance industry. technology can } \\
\text { enable the sector to significantly } \\
\text { increase old client engagement and } \\
\text { trust issues and create a variety of } \\
\text { new products }\end{array}$ \\
\hline 14 & $\begin{array}{l}\text { Challenges for } \\
\text { the Insurance } \\
\text { Industry in the } \\
\text { Future. }\end{array}$ & $\begin{array}{l}\text { Jack E. } \\
\text { Nicholson }\end{array}$ & 2019 & $\begin{array}{l}\text { Discussing some } \\
\text { insurance-related } \\
\text { developments and } \\
\text { trends presented in } \\
\text { May } 2019 \text { at Florida } \\
\text { State University } \\
\text { Future of Insurance } \\
\text { Forum, including the } \\
\text { role of technology } \\
\text { and disaster exposure }\end{array}$ & Qualitative Research & 57 & $\begin{array}{l}\text { Traditional insurers are challenged } \\
\text { by new insurers, who are designing } \\
\text { new business models to capitalize } \\
\text { on inefficiencies that disrupt } \\
\text { traditional markets. }\end{array}$ & $\begin{array}{l}\text { The future insurance industry } \\
\text { workforce must be flexible and } \\
\text { creative, continue their education, } \\
\text { think broadly about the global } \\
\text { business environment, and prepare } \\
\text { for rapid change. }\end{array}$ \\
\hline 15 & $\begin{array}{c}\text { Blockchain-based } \\
\text { data management } \\
\text { and analytics for } \\
\text { micro-insurance } \\
\text { applications }\end{array}$ & $\begin{array}{l}\text { Hoang Tam } \\
\text { Vo, Lenin } \\
\text { Mehedy, } \\
\text { Mukesh } \\
\text { Mohania, } \\
\text { and Ermyas } \\
\text { Abebe }\end{array}$ & 2017 & $\begin{array}{l}\text { Demonstrate } \\
\text { blockchain-based } \\
\text { solutions for } \\
\text { managing and } \\
\text { analyzing data } \\
\text { transparently in } \\
\text { pay-as-you-go } \\
\text { car insurance } \\
\text { applications }\end{array}$ & $\begin{array}{l}\text { Quantitative } \\
\text { Research }\end{array}$ & 8 & $\begin{array}{l}\text { Data management issues. Some } \\
\text { technical decisions need to be made } \\
\text { when implementing blockchain } \\
\text { technology as part of a database } \\
\text { solution for microinsurance } \\
\text { applications. }\end{array}$ & $\begin{array}{l}\text { It still requires deeper research } \\
\text { because it is expected that } \\
\text { blockchain-based solutions } \\
\text { to manage and analyze data } \\
\text { transparently }\end{array}$ \\
\hline
\end{tabular}




\begin{tabular}{|c|c|c|c|c|c|c|c|c|}
\hline 16 & $\begin{array}{l}\text { Digitalization } \\
\text { in insurance } \\
\text { companies }\end{array}$ & $\begin{array}{l}\text { Krzysztof } \\
\text { ŁYSKAWA, } \\
\text { Arleta } \\
\text { KĘDRA, } \\
\text { Lyubov } \\
\text { KLAPKIV, } \\
\text { and Jurij } \\
\text { KLAPKIV }\end{array}$ & 2019 & $\begin{array}{l}\text { Characterize the } \\
\text { process of digitization } \\
\text { in insurance } \\
\text { companies through } \\
\text { the application of } \\
\text { information and } \\
\text { communication } \\
\text { technology (ICT) }\end{array}$ & $\begin{array}{l}\text { Mixed-methods } \\
\text { Methodology }\end{array}$ & 44 & $\begin{array}{l}\text { The study examined the relationship } \\
\text { between the information technology } \\
\text { costs of selected insurance } \\
\text { companies and the results of their } \\
\text { activities. }\end{array}$ & $\begin{array}{l}\text { digitization in insurance becomes } \\
\text { an important topic in science; There } \\
\text { is some ambiguity of understanding } \\
\text { of definitions, structures, and } \\
\text { mechanisms of digitization in } \\
\text { insurance. Information technology } \\
\text { is generally accepted as an attribute } \\
\text { of digitization }\end{array}$ \\
\hline 17 & $\begin{array}{l}\text { Measuring } \\
\text { Efficiency of } \\
\text { Life Insurance } \\
\text { Institution in } \\
\text { Indonesia: Data } \\
\text { Envelopment } \\
\text { Analysis } \\
\text { Approach }\end{array}$ & $\begin{array}{l}\text { Aam Slamet } \\
\text { Rusydiana, } \\
\text { and Taufiq } \\
\text { Nugroho }\end{array}$ & 2017 & $\begin{array}{l}\text { The efficiency of } \\
\text { the life insurance } \\
\text { industry in Indonesia. } \\
\text { The calculation of } \\
\text { efficiency levels in } \\
\text { this study is relative, } \\
\text { not absolute. The } \\
\text { approach used is } \\
\text { Data Envelopment } \\
\text { Analysis (DEA). }\end{array}$ & $\begin{array}{c}\text { Literature Analysis } \\
\text { and Comparative } \\
\text { Method }\end{array}$ & 17 & $\begin{array}{l}\text { The results have implications for } \\
\text { the life insurance industry, both } \\
\text { conventional and sharia in Indonesia }\end{array}$ & $\begin{array}{l}\text { Life insurance both conventional } \\
\text { and sharia needs to calculate the } \\
\text { level of efficiency periodically } \\
\text { to know the level of efficiency, } \\
\text { potential improvement, and } \\
\text { excellence in general in the } \\
\text { framework of efficiency analysis. }\end{array}$ \\
\hline 18 & $\begin{array}{l}\text { The impact of } \\
\text { digitalization on } \\
\text { the insurance } \\
\text { value chain and } \\
\text { the insurability } \\
\text { of risks }\end{array}$ & $\begin{array}{l}\text { Martin Eling } \\
\text { and Martin } \\
\text { Lehmann }\end{array}$ & 2018 & $\begin{array}{l}\text { Analyze the impact of } \\
\text { digital transformation } \\
\text { on the insurance } \\
\text { sector using Porter's } \\
\text { value chain }\end{array}$ & $\begin{array}{l}\text { Mixed-methods } \\
\text { Methodology }\end{array}$ & 84 & $\begin{array}{l}\text { This paper is a comprehensive } \\
\text { review of the impact of digitization } \\
\text { on the insurance industry. It creates } \\
\text { databases of studies, articles and } \\
\text { working papers, and systematically } \\
\text { evaluates the impact of digitization } \\
\text { concerning Porter's value chain and } \\
\text { Berliner's insurability criteria }\end{array}$ & $\begin{array}{l}\text { So far there has been little academic } \\
\text { research on digitization in the } \\
\text { insurance segment. This seems } \\
\text { surprising, given that digitization } \\
\text { and big data offer enormous } \\
\text { potential for empirical research. }\end{array}$ \\
\hline 19 & $\begin{array}{l}\text { Enacting actuarial } \\
\text { fairness in } \\
\text { insurance: From } \\
\text { fair discrimination } \\
\text { to behavior-based } \\
\text { fairness }\end{array}$ & $\begin{array}{l}\text { Gert Meyers, } \\
\text { and Ine Van } \\
\text { Hoyweghen }\end{array}$ & 2018 & $\begin{array}{l}\text { The idea that } \\
\text { insurance products } \\
\text { should primarily be } \\
\text { 'fair' to policyholders } \\
\text { is increasingly voiced } \\
\text { by commentators }\end{array}$ & $\begin{array}{l}\text { Mixed-methods } \\
\text { Methodology }\end{array}$ & 67 & $\begin{array}{l}\text { Actuarial fairness is enforced by the } \\
\text { insurance industry as a necessity of } \\
\text { actuarial evidence to discriminate or } \\
\text { segment policyholders in insurance. }\end{array}$ & $\begin{array}{l}\text { In this article, we analyze the two } \\
\text { ways in which actuarial justice, the } \\
\text { descriptive neoclassical economic } \\
\text { concept, is enforced in insurance } \\
\text { practices and how this endorsement } \\
\text { relates to changes in assumptions } \\
\text { about economic actors. }\end{array}$ \\
\hline
\end{tabular}

was reported that the value and assets of the company were not enough to cover all the losses. So, it would be running all over again with adjustments made to the insurance policy.

A research study showed the dilemma between theoretical background and the practical realization of digitalization processes in insurance (Lyskawa, 2019). However, both the technology and insurance industry are now hard to separate. A study done provided a statement that the insurance industry is in a period of technologydriven change globally (Zheng et al., 2020). Nowadays, technological developments in insurance companies in the international arena have developed rapidly (Mustafina et al., 2020). This means, most of the process has gone through digitalization. In Jiwasraya's case, due to many customers, the company uses database-based storage so that data management can be done quickly and efficiently online. To improve efficiency, data management must be done using an automatic synchronization system so that all changes made will be updated immediately and well connected. Based on this, we could say that Jiwasraya followed the trend of any other similar cases for insurance companies, and the technology usage of those companies would be quite a fit for PT Asuransi Jiwasraya. Digitalization is the integration of the analog and digital worlds with new technologies that enhance customer interaction, data availability, and business processes (Nicholson, 2019). Spender et al. (2019) mentioned numerous relevant technologies in the fields of data acquisition and analysis (artificial intelligence, big data, Internet of things), data storage (blockchain, cloud computing), and communication (apps, chatbots, Roboadvisor, web pages, social networks, messenger, video calls, video platforms).

All of these bring new opportunities for business development. It can also be said that "financial technology" helps the insurance industry (Vo et al., 2017). This is supported by Shinde, vocalizing that the role of IT in insurance has always been a critical one (Shinde, 2019).
Primarily, given the long-term nature of products sold, technology becomes a very key component for onboarding, retaining, and servicing customers. On the other side, there is also stated that most of the insurers in the industry will continue to implement new technologies in their mix to remain competitive while distributing it through new and old means (Mosleh, 2019). From here, we can assume that database as one familiar type of data-storing and management system is most likely has and will be consistently used in the industry. So, despite the changes in the insurance policy, it is safe to assume that the existing database would not be abandoned but modified or adopted instead.

The conclusion in the previous paragraph is also supported by the fact that it would be a hassle for the company to manually sort and change the data too. Literacy and public awareness about insurance have developed from year to year, so there must be a lot of data stored and it would take a literal long time to manually adjust them or build a brand-new database (Safitri, 2020). Yet, this change would leave inevitable damage since fundamentally, insurance is about the pricing and selection of risk (Naylor, 2017). However, both could have changed from one type to another depending on technology's growth and the change itself will be complex. It might be a solution, but not a completely safe one, as Eling and Lehmann (2018) stated that digitalization and automatization influence all the business processes (e.g., automated processing of contracts) and the decision-making process, including the risk assessment (e.g., automated underwriting with artificial intelligence and big data), digitalization changes existing products (e.g., telematics insurance) and allows new product offerings (e.g., cyber risk insurance). Rusydiana and Nugroho (2017) also provided support saying digitalization changes the way insurers and customers interact which made it more concrete that this could be a risky step. Worse, Meyers and Hoyweghen (2018) assumed that dynamics of adverse selection will result in the bankruptcy of insurance providers. 


\subsection{Analysis of Real Actions}

From the technological point of view, there is a simpler and less risky method that could be used. All the data needed could be integrated into another database. This option is considered simpler since all the needed data will be transferred by the system and directly goes into a new database. Therefore, there won't be more effort and cost for data recollection which is not relevant as Jiwasraya has owned the proceeded data. Input would also be done by system and data that is no longer used will simply be excluded. By doing so, we could also lessen the time taken and the cost for human resources which we believe is important as Jiwasraya had gone through such a huge loss. Going this way, we could also lower data loss and security risk during the transfer. Throughout data migration, data across various separate data holders must be moved to one position where the convergence occurs (Iqbal et al., 2020). Data holders will be obligated to control who handles their data and how they interpret it. Research showed that this is possible since the results point out that the evaluation tiers' performance, scalability, elasticity, and consistency are well supported, in contrast to resource selection and availability (Seybold et al., 2017). Further, the analyzed frameworks do not support cloud-centric requirements but support classic evaluation requirements.

Another study supported this method saying that it is possible to use the bottom-up approach as it is used only when the distributed database already exists, and we just add another database to an existing setting (Rana, 2018). The bottom-up approach method occurs in two steps, namely Schema Translation and Schema Generation which both help the process of converting each data source schema into a common representation to make it easier to analyze and process (Rachman et al., 2017). Using a big data platform combined with space-time data could integrate its own data resources and provide cost reduction, followed by risk prevention which is pretty much helpful for business (Liu et al., 2018). This could also be an option. Usage of Big Data could be implemented by keeping all the data in cloud-based storage for both short and long periods. Data stored should be synchronized from both sides, named the data owner or the one that uploads it to the cloud and data editor or the ones that receive access to those data. By then, the editor may gain the old data right into their new database. Longterm usage would be helpful in the transition too, as the user could easily stick to their old database which they surely are more familiar with, and let the cloud synchronize the data for the new database. It could be constantly implemented until the new database is considered fit, comfortable, and familiar enough for users to completely move. Therefore, it is ultimately possible for PT Asuransi Jiwasraya to use one of the methods above to create and manage its new policy.

\section{CONCLUSION}

Policy reconstruction of PT Asuransi Jiwasraya is a hard yet possible choice in an effort of reducing the company lost due to the case. Since moving and adapting all the data manually is a lot of work, the existence of a database used would be a great help. By applying the integrated database concept, the overall data could be directly moved to a newadapted database. This solution is doable due to the nature of the old database is already organized. Well-organized data give the most benefit for effective queries and faster processes. Therefore, the company can access and mutate the data by doing specific queries that are needed. Mostly, it is an effective solution to move the entire data without any significant changes, except for adding and removing some fields. This solution may be used in many other industries by adjusting the data by manipulating it slightly. Nevertheless, the Cloud-centric database option might not be ready for use by now, but this could be an open choice for the future.

\section{REFERENCES}

Ashmarina, S., Sarmento, A., \& Vochozka, M. (Eds.). (2020). Digital Transformation of the Economy: Challenges, Trends and New Opportunities. Springer.

Eling, M., \& Lehmann, M. (2018). The impact of digitalization on the insurance value chain and the insurability of risks. The Geneva papers on risk and insurance-issues and practice, 43(3), 359-396.

Gusti, G. P. (2019). Analysis of the cause of loss of PT. Asuransi Jiwasraya (Persero). Jurnal Manajemen dan Bisnis Sriwijaya, 17(4), 199-206.

Iqbal, H., Habli, M., \& Zeki, T. Enhance Confidentiality by the usage of a Database Management Framework Features to Facilitate Applications Integration.

Liu, Y., Peng, J., \& Yu, Z. (2018, August). Big data platform architecture under the background of financial technology: In the insurance industry as an example. In Proceedings of the 2018 International Conference on Big Data Engineering and Technology (pp. 31-35).

Łyskawa, K., Kędra, A., Klapkiv, L., \& Klapkiv, J. (2019, May). Digitalization in insurance companies. In International Scientific Conference: Contemporary Issues in Business, Management and Economics Engineering (pp. 9-10).

Meyers, G., \& Van Hoyweghen, I. (2018). Enacting actuarial fairness in insurance: From fair discrimination to behaviour-based fairness. Science as Culture, 27(4), 413-438.

Mosleh, N. (2019). Impact of Technology on Insurance Industry.

Naylor, M. (2017). Insurance transformed: technological disruption. Springer.

Nicholson, J. E. (2019). Challenges for the Insurance Industry in the Future. Journal of Insurance Regulation, 38(6).

Rana, M. S., Sohel, M. K., \& Arman, M. S. (2018). Distributed Database Problems Approaches and Solutions-A Study. In International Journal of 
Machine Learning and Computing (IJMLC).

Rachman, M. A. F., \& Saptawati, G. A. P. (2017, November). Database integration based on combination schema matching approach (case study: Multi-database of district health information system). In 2017 2nd International conferences on Information Technology, Information Systems and Electrical Engineering (ICITISEE) (pp. 430435). IEEE.

Rusydiana, A. S., \& Nugroho, T. (2017). Measuring Efficiency of Life Insurance Instution in Indonesia: Data Envelopment Analysis Approach. Global Review of Islamic Economics and Business, 5(1), 012-024.

Safitri, K. A. (2020, April). Contribution of Technology to Insurance in Indonesia. In 3rd International Conference on Vocational Higher Education (ICVHE 2018): "Understanding Digital World. From Theory to Practices.” (pp. 78-83). Atlantis Press.

Seybold, D., \& Domaschka, J. (2017, September). Is distributed database evaluation cloud-ready?. In European Conference on Advances in Databases and Information Systems (pp. 100-108). Springer, Cham.

Shinde, O. (2019). Use of Information Technology in Insurance Industry. Bimaquest, 19(3).

Spender, A., Bullen, C., Altmann-Richer, L., Cripps, J., Duffy, R., Falkous, C., ... \& Yeap, W. (2019). Wearables and the internet of things: Considerations for the life and health insurance industry. British Actuarial Journal, 24.

Trihatmoko, R. A., \& Kuncoro, M. (2021). A Review on the Settlement of 'Jiwasraya' Case: A Study of Governance of State-Owned Enterprises (SOEs) Based on the Indonesian Economic Constitution. Journal of Business Administration and Education, 13 .

Vo, H. T., Mehedy, L., Mohania, M., \& Abebe, E. (2017, November). Blockchain-based data management and analytics for micro-insurance applications. In Proceedings of the 2017 ACM on Conference on Information and Knowledge Management (pp. 2539-2542).

Zheng, L., \& Guo, L. (2020, April). Application of Big Data Technology in Insurance Innovation. In International Conference on Education, Economics and Information Management (ICEEIM 2019) (pp. 285-294). Atlantis Press. 